\title{
The Effect of Clove Essential Oil Treatment on the Cell Wall Components of Wheat Straw
}

\author{
Hülya Özelçam ${ }^{1}$, Sema Özüretmen ${ }^{1}$, Hasan Hüseyin İpçak ${ }^{1}$ and Aylin Dereboylu ${ }^{2}$ \\ 1. Department of Animal Science, Faculty of Agricultural, Ege University, İzmir 35100, Turkey \\ 2. Department of Biology, Faculty of Science, Ege University, İzmir 35100, Turkey
}

\begin{abstract}
The aim of this study was to determine the effects of additions of different doses of clove oil (Syzygium aromaticum L.) on cell wall component of wheat straw. For this purpose, wheat straw was treated with $100 \mathrm{ppm}$ and $200 \mathrm{ppm}$ clove oil and applied at two different time period $(1 \mathrm{~h}$ and $5 \mathrm{~h}$ ). The microscopic analysis was made on cell wall components of untreated and treated of the straw. According to the research findings, with increasing doses and time of clove oil treatment, particularly, neutral detergent fiber (NDF) and acid detergent fiber (ADF) content of straw significantly $(P<0.05)$ reduced, approximately at the level of $15 \%$ for NDF and $13 \%$ for ADF, respectively. The lowest NDF, ADF, acid detergent lignin (ADL) and cellulose contents were found in $200 \mathrm{ppm}$ dose and $5 \mathrm{~h}$ period. However, the lowest stem section thickness likewise was determined in $5 \mathrm{~h}$ period $(P<0.05)$, but there was no significant difference between the dose. Consequently, it could be said that the addition of clove oil have a positive influence on cell wall components and stem section thickness of wheat straw.
\end{abstract}

Key words: Wheat straw, clove oil, cell wall components.

\section{Introduction}

Structural carbohydrates within the structure of straws are essentially of lignocellulosic structure (30\%-50\% cellulose $+25 \%-30 \%$ hemicellulose + $10 \%-20 \%$ lignin) [1]. The structure expressing cell walls of feeds is named as neutral detergent fiber $(\mathrm{NDF}=$ hemicelluloses + cellulose + lignin $)$, and it is particularly important in the preparation of dairy cattle rations. As a matter of fact, NDF is tightly correlated with feed intake, rumination and chewing time [2]. Cellulose and lignin content of feeds are designated as acid detergent fiber (ADF) and its low level is desired in the feed. The acid detergent lignin (ADL) can form strong chemical bonds with the cellulose and hemicellulose of the feed, and lignocellulosic structure is generally regarded as indigestible. Thus, the lignocellulosic structure shows resistance against microbial enzymes during in the rumen fermentation, thereby decreasing the digestibility of the straw [3].

Corresponding author: Hülya Özelçam, professor, research fields: forages, silage, ruminant nutrition, nylon bag technique.
So far, attempts have been made to degrade the bonds of lignocellulosic structure within these wheat straws and to enhance the digestibility level of the straws. To that end, various physical, chemical [4-6] and microbiological [7] studies have been performed $[8,9]$. Thus, there can be seen the thickened cell wall structure in the unprocessed wheat straw, while polysaccharides are decomposed a little in steam treatment, and the bonds between hemicellulose and lignin are degraded in alcohol treatment [10]. On the other hand, it has been revealed in the researches that etheric oils have effects on the ruminal digestibility of the feed [11-13]. The reason is that the etheric oils have a fetal effect on bacteria with its special effect mechanism. This mechanism impairs the electron, ion or $\mathrm{K}$ balance within the cell wall, causing shrinking and death of bacteria via effusing the cell content out $[14,15]$.

Furthermore, it is reported that this effect of etheric oils is increased or decreased in accordance with time $[16,17]$. The effect left on the dead cell tissue by the etheric oils has not yet been observed. However, it has 
been revealed that upon clove oil addition to the wheat straw, in vitro digestibility and metabolizable energy value of the feed are increased [18]. In fact, clove oil (Syzygium aromaticum L.) is an etheric oil type having strong antimicrobial, antifungal and therapeutic features with the main component eugenol [19-22].

The aim of this study was to reveal the effect of treatment with clove oil in different dose and time periods on the cell wall components of wheat straw.

\section{Materials and Methods}

The materials of the study consist of wheat straw and clove oil with $66.59 \%$ eugenol. A total of four treatment groups including one control (without clove oil addition) were formed. Wheat straws $(1,000 \mathrm{~g})$ were treated with $100 \mathrm{ppm}$ and $200 \mathrm{ppm}$ clove oil and at $1 \mathrm{~h}$ and $5 \mathrm{~h}$ time periods. Clove oil was sprayed on wheat straw, which was weighed into the polyethylene bags by a spray bottle. During the treatment, the straws were kept in dry and dark environment. At the end of the treatment, the straws were ground in $1 \mathrm{~mm}$ screen, and the cell wall components were determined.

The NDF, ADF and ADL components of the straws were determined in accordance with Van Soest analysis method. Moreover, the hemicellulose contents of the straws were calculated from NDF-ADF difference and cellulose contents from ADF-ADL difference [23], as Eqs. (1) and (2):

$$
\begin{aligned}
& \text { Hemicellulose } \%=\text { NDF } \%-\text { ADF } \% \\
& \text { Cellulose } \%=\text { ADF } \%-\text { ADL } \%
\end{aligned}
$$

Furthermore, microscopic analyses of the straws
(Olympus bx-51, C-5050) were performed, and the sectional thickness of cell wall was determined as well. Image-Pro Express image analysis program has been used in the calculation of the cell wall sectional thicknesses. Analyses were conducted in two different days. In each day, four replicates for each sample were studied.

SPSS (SPSS version 21) package program (multivariate analysis of variance (MANOVA)) has been used in statistical evaluation of the data obtained from the study. In comparison of the differences between the mean values, Duncan multiple comparison test $(P<0.05)$ has been used [24].

\section{Results and Discussion}

In the study, the effect of clove oil on the wheat straw cell wall components on different dose and time periods has been investigated. As known, cell wall is a complex structure made of hemicellulose, cellulose and lignin. Particularly lignin can form strong bonds with hemicellulose and cellulose on the cell wall, thus, decreasing the digestibility of the straws. So, lignin has to be degraded for the digestibility in the rumen to occur. However, rumen microorganisms are inadequate in degrading this hard structure [25]. To that end, a plurality of delignification studies has been performed. Nevertheless, there has not been any study pertaining to positive or negative effect of etheric oils on cell wall components.

In the study, the effect of clove oil treatment with wheat straw on cell wall components with different doses and times is presented in Table 1. Accordingly,

Table 1 Effect of clove oil treatment on cell wall component of wheat straw with different doses and times (in dry matter\%).

\begin{tabular}{llllll}
\hline Clove oil & NDF & ADF & ADL & Hemicellulose & Cellulose \\
\hline Control & $75.39 \pm 1.34^{\mathrm{a}}$ & $45.19 \pm 0.23^{\mathrm{a}}$ & $10.18 \pm 0.76^{\mathrm{a}}$ & $30.20 \pm 1.26^{\mathrm{a}}$ & $35.28 \pm 0.89^{\mathrm{a}}$ \\
$100 \mathrm{ppm}, 1 \mathrm{~h}$ & $70.30 \pm 0.64^{\mathrm{b}}$ & $42.71 \pm 0.49^{\mathrm{b}}$ & $9.39 \pm 0.89^{\mathrm{ab}}$ & $27.59 \pm 0.77^{\mathrm{ab}}$ & $33.32 \pm 1.12^{\mathrm{ab}}$ \\
$200 \mathrm{ppm}, 1 \mathrm{~h}$ & $65.48 \pm 1.04^{\mathrm{cd}}$ & $41.55 \pm 0.67^{\mathrm{b}}$ & $8.65 \pm 0.43^{\mathrm{ab}}$ & $23.93 \pm 1.40^{\mathrm{c}}$ & $33.47 \pm 0.67^{\mathrm{ab}}$ \\
$100 \mathrm{ppm}, 5 \mathrm{~h}$ & $67.16 \pm 0.92^{\mathrm{c}}$ & $41.46 \pm 0.34^{\mathrm{b}}$ & $9.54 \pm 0.29^{\mathrm{ab}}$ & $24.65 \pm 1.04^{\mathrm{bc}}$ & $31.86 \pm 0.74^{\mathrm{bc}}$ \\
$200 \mathrm{ppm}, 5 \mathrm{~h}$ & $63.74 \pm 0.19^{\mathrm{d}}$ & $39.18 \pm 1.22^{\mathrm{c}}$ & $7.75 \pm 0.24^{\mathrm{b}}$ & $24.62 \pm 1.00^{\mathrm{bc}}$ & $30.20 \pm 0.19^{\mathrm{c}}$ \\
$P$ value & 0.00 & 0.00 & 0.03 & 0.00 & 0.01 \\
\hline Dose $\times$ time & $63.23 \pm 0.89$ & $39.02 \pm 0.43$ & $8.41 \pm 0.26$ & $24.20 \pm 0.66$ & $30.61 \pm 0.48$ \\
$P$ value & 0.16 & 0.20 & 0.18 & 0.06 & 0.97 \\
\hline
\end{tabular}

The differences between means in the same column with different letters are significant $(P<0.05)$. 
Table 2 Effect of clove oil treatment on sectional thickness of wheat straw with different doses and times.

\begin{tabular}{lllllll}
\hline Clove oil & Control & $100 \mathrm{ppm}, 1 \mathrm{~h}$ & $200 \mathrm{ppm}, 1 \mathrm{~h}$ & $100 \mathrm{ppm}, 5 \mathrm{~h}$ & $200 \mathrm{ppm}, 5 \mathrm{~h}$ & $P$ value \\
\hline Sectional thickness $(\mu \mathrm{m})$ & $297.2 \pm 6.9^{\mathrm{a}}$ & $200.1 \pm 2.6^{\mathrm{b}}$ & $167.9 \pm 2.5^{\mathrm{c}}$ & $120.6 \pm 5.7^{\mathrm{d}}$ & $110.2 \pm 4.0^{\mathrm{d}}$ & 0.00 \\
\hline
\end{tabular}

The differences between means in the same row with different letters are significant $(P<0.05)$.

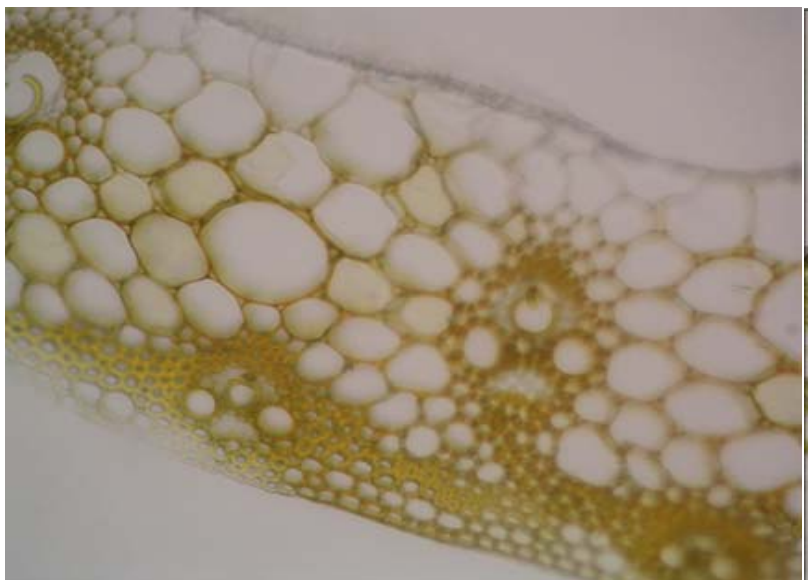

(a) General image of cell wall in the wheat straw

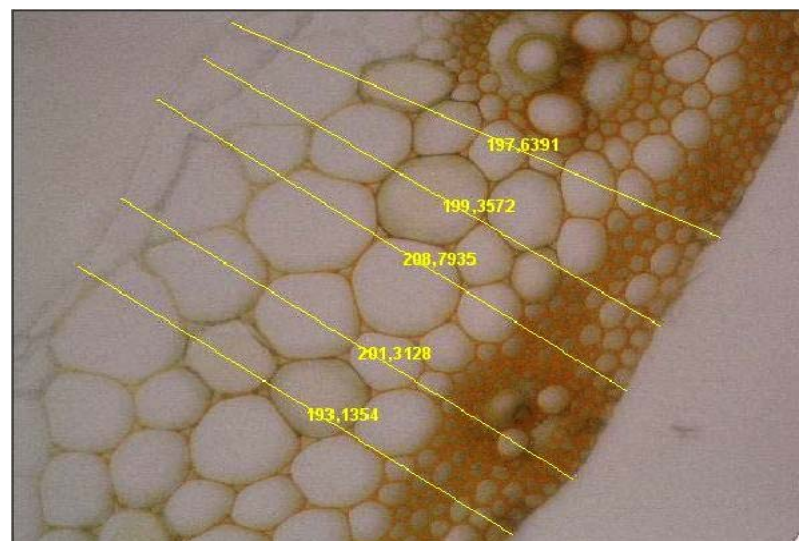

(c) Treated with clove oil (100 ppm, $1 \mathrm{~h})$

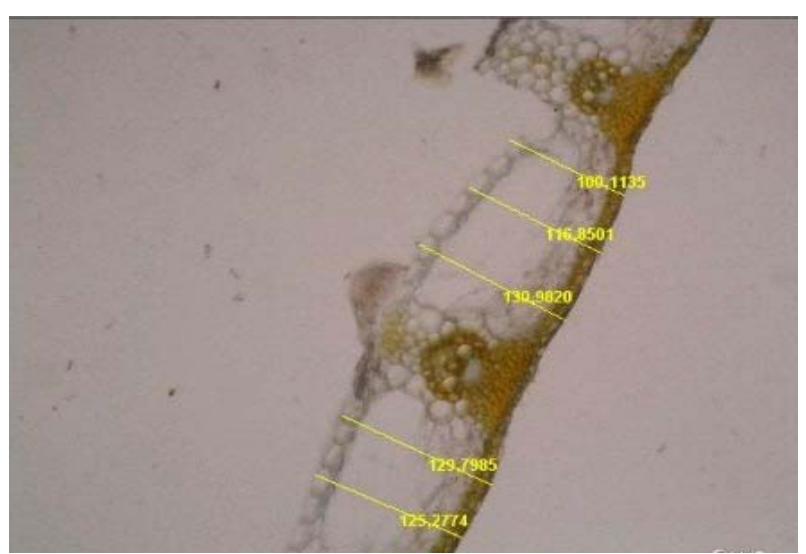

(e) Treated with clove oil (100 ppm, 5 h)

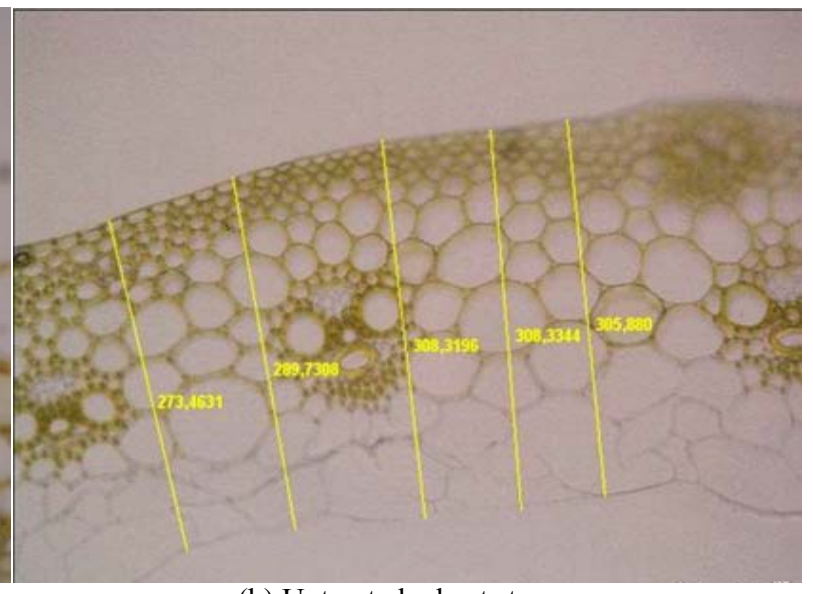

(b) Untreated wheat straw

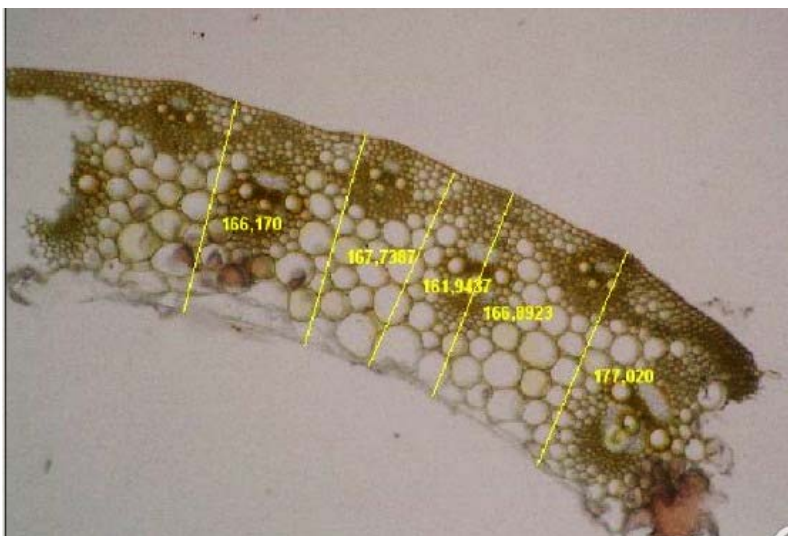

(d) Treated with clove oil (200 ppm, 1 h)

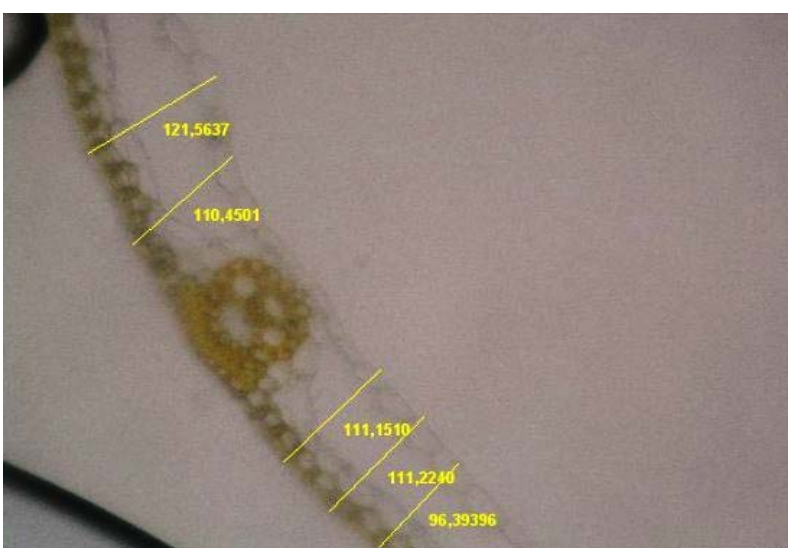

(f) Treated with clove oil (200 ppm, 5 h)

Fig. 1 The light microscopy images of the wheat straw treated with clove oil at different dose and time period.

it has been detected that with increasing of dose and time, the clove oil has decreased the cell wall components of wheat straw significantly $(P<0.05)$.
This decrease in $5 \mathrm{~h} 200 \mathrm{ppm}$ group, with respect to the control group, is $15 \%, 13 \%, 24 \%, 21 \%$ and $14 \%$ for NDF, ADF, ADL, hemicellulose and cellulose, 
respectively. Moreover, the greatest decrease has been found in $200 \mathrm{ppm}$ dose and $5 \mathrm{~h}$ period, except for hemicellulose. While, the greatest decrease for hemicelluloses is found in $200 \mathrm{ppm}$ dose and $1 \mathrm{~h}$ period.

On the other hand, Sun et al. [26] have reported that $6 \mathrm{~h}$ treatment of wheat straw with alkaline has enabled the degradation of ester bonds between ferulic acid, polysaccharide or p-coumaric acid and lignin within the cell wall. While, Sirohi and Rai [27] have reported that treatment of wheat straw with lime has caused decrease in NDF and ADL content, and the greatest decrease compared to the control group is in the 3rd week. Nasehi et al. [9] have shown that NDF, ADF and ADL rates have decreased in enzyme-treated wheat straw, while crude protein, and in situ dry matter and organic matter digestibility have increased.

In the study, the effect of clove oil treatment with wheat straw on cell wall sectional thickness of straw with different doses and times is presented in Table 2. Accordingly, it has been determined that with increasing of the dose and time, the clove oil has thinned the cell wall sectional thickness of wheat straw significantly $(P<0.05)$. The greatest thinning has been found in $200 \mathrm{ppm}$ dose and $5 \mathrm{~h}$ period (110.2 $\mu \mathrm{m})$, with respect to the control group $(297.2 \mu \mathrm{m})$. Also, it has been seen in the images obtained from light microscopy (Fig. 1) that cortical parenchyma cells are swollen in the 1st hour, and partially or completely decomposed in the 5th hour, and also there are partial degradations on the epidermis (cuticula) layer in the 5th hour.

In the present study, it is presented that the clove oil treatment with wheat straw has significantly decreased the cell wall components (Table 1) and also thinned the sectional thickness (Table 2). Actually, it is seen in the microscopic images that the cells have swollen in the 1st hour, and there is the explosion of cell within the middle layer and thinning in the 5th hour. The situation is considered to be resulted from the entering of the etheric oil into the cell via diffusion, thereby increasing the turgor pressure within the cell. Also in the study, it is seen that the effect of the clove oil has changed in accordance with dose and time, however, dose $\times$ hour interaction does not matter (Table $1, P>$ $0.05)$.

\section{Conclusions}

Consequently, it can be said that the treatment of wheat straw with the clove oil has a decreasing effect on the cell wall components with increasing of the dose and time. Accordingly, the NDF, ADF, ADL and cellulose content of wheat straw were observed the greatest decrease in $200 \mathrm{ppm}$ dose and $5 \mathrm{~h}$. Microscopic analyses have found compatible with the chemical analysis results. But it must be examined by microscope, such as scanning electron microscope (SEM) to see more detail about the effect of clove oil on cell wall components of wheat straw. In vivo studies are required to see the clove oil treatment of wheat straw on the animals.

\section{Acknowledgments}

The authors would like to thank academician Assoc. Prof. Dr. Yiğit Uyanikgil and the Department of Histology and Embryology, Faculty of Medicine, Ege University for their contributions to the present study.

\section{References}

[1] Smill, V. 1999. "Crop Residues: Agriculture's Largest Harvest." BioScience 49 (4): 299-308.

[2] Allen, M. S. 1997. "Relationship between Fermentation Acid Production in the Rumen and the Requirement for Physical Effective Fiber.” J. Dairy Sci. 80 (7): 1447-62.

[3] McDonald, P., Edwards, R. A., and Greenhalgh, J. F. D. 1988. Animal Nutrition, 4th ed.. Essex, England: Longman.

[4] Çakmak, C., Çerçi, İ. H., Çetinkaya, N., and Koçak, D. 1993. "The Effects of Chemical Treatments of Wheat Straw upon Its Ruminal Degradability and Metabolizable Energy.” J. Lalahan Animal Res. Inst. 33 (3-4): 58-68.

[5] Çerçi, H., and Sarı, M. 1990. "The Effects of Diets Containing Different Roughages (Alfalfa Hay, Barley Straw, Barley Straw-HCl) on the Digestibility and N-Retention in Goats." Selçuk Uni. J. of Vet. Fac. 6 (1): 47-51. 
[6] Çerçi, H., Güler, T., Şahin, K., Bayraktar, M., and Özbey, O. 1996. "The Effects of $\mathrm{NaHCO}_{3}$ and Straw Added Diets on Feedlot Performance in Sheep.” J. Vet. Fac. 12 (1): $97-102$

[7] Kalkan, H., and Filya, İ. 2011. "Effects of Cellulase Enzyme on Nutritive Value, in Vitro Digestion Characteristics and Microbial Biomass Production of Wheat Straw." Kafkas Univ. J. of Vet. Fac. 17 (4): 585-94.

[8] Lawther, J. M., Sun, R., and Banks, W. B. 1995. "Extraction, Fractionation and Characterization of Structural Polysaccharides from Wheat Straw." J. Agric. Food Chem. 43 (3): 667-75.

[9] Nasehi, M., Torbatinejad, N. M., Zerehdaran, S., and Safaei, A. R. 2014. "Effect of (Pleurotus florida) Fungi on Chemical Composition and Rumen Degradability of Wheat and Barley Straw." Iranian J. App. Animal Sci. 4 (2): 257-60.

[10] Chen, H. Z., and Liu, L. Y. 2007. "Unpolluted Fractionation of Wheat Straw by Steam Explosion and Ethanol Extraction." Bioresour. Technol. 98 (3): 666-76.

[11] Ghosh, S., Mehla, R. K., Sirohi, S. K., and Roy, B. 2010. "The Effect of Dietary Garlic Supplementation on Body Weight Gain, Feed Intake, Feed Conversion Efficiency, Faecal Score, Faecal Coliform Count and Feeding Cost in Crossbred Dairy Calves." Trop. Anim. Health Prod. 42 (5): 961-8.

[12] Huang, Y., Yoo, J. S., Kim, H. J., Wang, Y., Chen, Y. J., Cho, J. H., and Kim, I. H. 2010. "Effects of Dietary Supplementation with Blended Essential Oils on Growth Performance, Nutrient Digestibility, Blood Profiles and Fecal Characteristics in Weanling Pigs." Asian-Australian J. Anim. Sci. 23 (5): 607-13.

[13] Hashemi, S. R., and Davoodi, H. 2011. "Herbal Plants and Their Derivatives as Growth and Health Promoters in Animal Nutrition.” Vet. Res. Commun. 35 (3): 169-80.

[14] Lambert, R. J. W., Skandamis, P. N., Coote, P. J., and Nychas, G. J. E. 2001. "A Study of the Minimum Inhibitory Concentration and Mode of Action of Oregano Essential Oil, Thymol and Carvacrol." J. Appl. Microbiol. 91 (3): 453-62.

[15] Burt, S. 2004. "Essential Oils: Their Antimicrobial Properties and Potential Applications in Foods: A Review.” Int. J. Food Microbiol. 94 (3): 223-53.

[16] Bergvist, T. P. 2007. "Antimicrobial Activity of Four
Volatile Essential Oils." Master thesis, University of Gothenburg, Sweden.

[17] Chamdit, S., and Siripermpool, P. 2012. "Antimicrobial Effect of Clove and Lemongrass Oils against Planktonic Cells and Biofilms of Staphylococcus aureus." Mahidol Uni. J. of Pharmaceutical Sci. 39 (2): 28-36.

[18] Özüretmen, S. 2014. "Effect of Clove Oil Treatment in Vitro Organic Matter Digestibility and Metabolizable Energy Value of Wheat Straw." Master thesis, Department of Animal Science, Ege University, Izmir, Turkey.

[19] Srivastava, A. K., Srivastava, S. K., and Syamsundar, K. V. 2005. "Bud and Leaf Essential Oil Composition of Syzygium aromaticum from India and Madagascar." Flavour Fragr. J. 20 (1): 51-3.

[20] Machado, M., Dinis, A. M., Salgueiro, L., Custodio, J. B. A., Cavaleiro, C., and Sousa, M. C. 2011. "Anti-Giardia Activity of Syzygium aromaticum Essential Oil and Eugenol: Effects on Growth, Viability, Adherence and Ultra Structure." Exp. Parasitol. 127 (4): 732-9.

[21] Pérez, G. S., Ramos-López, M. A., Sánchez-Miranda, E., Fresán-Orozco, M. C., and Pérez-Ramos, J. 2012. “Antiprotozoa Activity of Some Essential Oils." J. Med. Plants Res. 6 (15): 2901-8.

[22] Farhath, S., Vijaya, P., and Vimal, M. 2013. "Immunomodulatory Activity of Geranial, Geranial Acetate, Gingerol and Eugenol Essential Oils: Evidence for Humoral and Cell-Mediated Responses." Avicenna J. Phytomedicine 3 (3): 224-30.

[23] Goering, H. K., and Van Soest, P. J. 1970. Forage Fiber Analyses. Washington, D.C.: United States Department of Agriculture.

[24] SPSS. 2012. SPSS Advanced Statistics. Version 21.0. Chicago, Illinois: SPSS Inc.

[25] Arora, D. S., and Sharma, R. K. 2009. "Comparative Ligninolytic Potential of Phlebia Species and Their Role in Improvement of in Vitro Digestibility of Wheat Straw." J. Anim. Feed Sci. 18 (1): 151-61.

[26] Sun, R., Lawther, J. M., and Banks, W. B. 1996. "Effects of Extraction Time and Different Alkalis on the Composition of Alkali-Soluble Wheat Straw Lignins." J. Agric. Food Chem. 44 (12): 3965-70.

[27] Sirohi, S. K., and Rai, S. N. 1999. "Synergistic Effect of Lime and Urea Treatment of Wheat Straw on Chemical Composition, in Sacco and in Vitro Digestibility." Asian-Australian J. Anim. Sci. 12 (7): 1049-53. 